\title{
The Individualisation of Responsibility and School Achievement
}

\author{
METKA MENCIN ČEPLAK* \\ University of Ljubljana
}

\begin{abstract}
Education is seen as an investment in 'human capital', and providing children with a good education is considered to be key to securing their future and their success in life. This article analyses how these discourses on education affect young people in the context of the dismantling of public services and growing social uncertainty. Surveys on youth in Slovenia in the late 1990s and 2000s indicate that children are exposed to the pressure of academic success very early in their lives. The article examines the symbolic meaning of academic achievement, the importance of school success in the educational path in post-socialist Slovenia, and its influence on teenagers' self-understanding and identity construction. The analysis is based on short narratives written by secondary school students about their experiences with school (under-) achievement. The wider social context is clarified based on some research and statistical data. The analysis leads to the conclusion that striving for school success is a response to the neoliberal process of individualising responsibility, which is also reflected in 'truths' about the importance of early child care for later academic achievement-these 'truths' can be understood as normalising discourses, which have an important influence on the construction of the self and the parent-child relationship.
\end{abstract}

Keywords: school achievement, Foucault, neoliberalism, discourse analysis, sociology of education, Slovenia

Sociologický časopis/Czech Sociological Review, 2012, Vol. 48, No. 6: 1093-1114

\section{Introduction}

Education is considered a crucial personal investment in the future, a condition for personal well-being, and a passport to a better and more secure future. These slogans about education can be heard repeatedly in insurance advertisements, political and school promotional campaigns, and even from parents (obviously, those who can afford schooling for their children) and teachers, cited as the 'magic words' to motivate children to excel at school.

This paper examines the experience of young people with school success/ failure and the high expectations of academic achievement in a social context of

\footnotetext{
* Direct all correspondence to: Metka Mencin Čeplak, Faculty of Social Sciences, University of Ljubljana, Kardeljeva Ploščad 5, SI-1000 Ljubljana, Slovenia.
}

(C) Sociologický ústav AV ČR, v.v.i., Praha 2012 
growing uncertainty and the individualisation of responsibility for social and personal welfare (i.e. responsibilisation) in the 1990s and 2000s in Slovenia. Striving to achieve a good education can be considered one of the main individual strategies for assuring personal security and certainty, and fulfilling the norm of the responsible, autonomous, rational individual, deployed in political and scientific discourses. My main premise is that both conditions-the dismantling of the welfare state and the rise of neoliberal discourse on individuals as 'entrepreneurs of the self' - raise the stakes in the case of eventual school failure, and strengthen the normalising effects of the norm of the 'good student' (and the responsible, attentive parent). Subjection to academic pressure (with its ultimate demand to become 'the best') can be considered, according to Foucault's analysis of disciplinary control and the concept of normalisation and subjectification [Foucault 1984, $2000,2008]$, as the effect of 'successful' subjection to the normalisation process.

\section{The marketisation of education and its effects-an overview of research to date}

Over the past twenty years the contradictory and damaging effects of the marketisation of education have been a significant area of theoretical analysis and research. The present overview focuses, first of all, on the imperative of competition and freedom of choice, or, according to Foucault [2008], on the imperative of improving 'human capital'.

Foucault [2008] argues that competition is the key regulatory principle of the neoliberal 'art of government' (or 'governmentality'). Neoliberal governmentality creates a new form of homo ceconomicus, 'the man of enterprise and production' [ibid.: 147], the 'entrepreneur of himself, being for himself the source of [his] earnings' [ibid.: 226]. The individual, the entrepreneur of himself, is the bearer of 'human capital' (skills, abilities and knowledge), made up of innate and acquired elements [ibid.: 226-227]. Within this view of the human being, parental childcare and education are also understood as an investment in the child's and one's own human capital [ibid. 2008: 229-230, 243-245]; improving human capital is the goal of various rational programmes, professional advice, training, and therapies that try to encourage behaviours among teachers, students, and parents aimed at improving their teaching, learning, parental skills, and achievements [e.g. Rose 1990, 1999; Holmer Nadesan 2002]; governmental politics of fostering competition can be considered as an attempt to increase the value of the population's human capital.

The intense competition for scarce educational resources reproduces or even exacerbates traditional social inequities, hierarchies, and segregation [e.g. Aronowitz and Giroux 1993; Whitty, Edwards and Gewirtz 1993; Ball, Bowe and Gewirtz 1994; Apple 1996, 2001, 2004; Gillborn and Youdell 2000; James et al. 2010]. Schools compete with each other for students, especially the ones considered 'good' and 'promising', for the 'best' teachers, and for positive public 
perceptions. An 'ethics of competition' [Webb, Briscoe and Mussman 2009] that employs several more or less anonymous techniques of constant surveillance has the effect of limiting teachers' power and can damage their interpersonal relationships when it encourages mutual surveillance.

In contradiction with the process of de-governmentalisation, but in the name of enhancing educational quality, school institutions have been subjected to increased centralised control: standards, national testing, a national curriculum, a definition of the objectives of education [Dale 1997; Robertson and Dale 2002; Apple 2004; Laval 2005; Hirtt 2008]. Several authors [e.g. Graham and Neu 2004; Webb 2007; Webb, Briscoe and Mussman 2009] consider standardised testing to be a strategy of governance based on panoptic modalities of power: students' test scores are considered not only as indicators of their knowledge, but also as the most important indicator of school quality and the 'quality' of teachers, principals, and parents. The visibility of testing results has serious and damaging effects on teaching, especially if it coerces teachers into subordinating their work with pupils to one overarching goal: improving students' test scores.

Educational studies warn against yet another threatening imperative of neoliberal educational policy: the employability imperative. Namely, promoting skills and competence, a growing work-orientation (work-related teaching, developing partnerships between schools and corporations), and promoting 'entrepreneurship' in education are the focus of neoliberal educational discourses. Critical authors warn that 'an obsession with "what works"' [Hill 2003] devaluates academic knowledge and reduces the space for critical education studies and research [e.g. Laval 2005; Hirtt 2008; Kaščák and Pupala 2010; Muršak 2010].

Students (or children in general) are the most numerous 'victims' of the 'ethics of competition'. Gillborn and Youdell [2000] show how constant competition between schools shifts the emphasis from student needs to student performance, from what the school does for the student to what the student does for the school. Several authors have investigated the contradictory processes of individualisation and responsibilisation under conditions of rationing educational opportunity and persisting (or even rising) class, gender, 'race', and sexual inequities. As Popkewitz and Brennan [1998: 8] point out, 'the very systems of reasoning that are to produce equality, justice, and diversity may inscribe systems of representation that construct 'otherness' through concrete pedagogical practices that differentiate, compare, and normalize children along a continuum of value'.

'Class-blindness' is a significant characteristic of several scientific and professional discourses. Hegemonic discourses on 'good' parenting, for example, emphasise the essential role of high quality early care for a child's cognitive, emotional, and social development and school achievement, parental involvement in the child's education (e.g. developmental psychology, pedagogy, and brain sciences), parental responsibility and competence. As a rule, they overlook the social obstacles and inequities that make this norm unattainable for families from deprivileged social backgrounds [e.g. Walkerdine 1984; Vincent and Tomlinson 
1997; Edwards and Alldred 2000; Holmer Nadesan 2002; Lareau 2003; Griffith and Smith 2005].

The neoliberal programme, according to Foucault [2008], does not seek to create either a disciplining or a normalising society. Pongratz [2011] and Kaščák and Pupala [2010,2011], for example, show how neoliberal educational reforms and pedagogical discourse on the autonomous and self-governing individual enable the effective operation of 'soft power' and the emergence of a society of control based on self-control. Nevertheless, school could still be considered to be one of the privileged places of constant examination and surveillance, as Foucault wrote in 1975. In the context of this article it is worth emphasising an unavoidable technique of disciplinary control in school: (constant) examination. Examination as a combination of hierarchical observation and normalising judgement is, according to Foucault [1984], an example of the power/knowledge relationship-it deploys force and establishes truth, it provides criteria for categorisation (e.g. in/capable, un/promising student) and correction. It is a complex technique, and examining is a multilevel process; its objects are the students and their parents, teachers and schools and their principals - all of them are the objects of (mutual!) surveillance and normalising judgement that can seriously affect their behaviour and perception of their identity. Examination, among other things, can result in school failure, and the fear of school failure can produce various disciplinary effects - or cause resistance, since resistance is, according to Foucault [2000], a side effect of power, something which escapes its intentions and control.

\section{Methodology}

This analysis is based primarily on 22 written reports/narratives by 17 - to 18-year-old grammar school students (Ljubljana, June 2004). These reports were collected in a qualitative research project on the genesis of school success/failure (conducted by the Centre for Social Psychology, University of Ljubljana, Faculty of Social Sciences, 2003-2005). This project explored the critical elements of hidden curricula (categorisation and stigmatisation), the symbolic meanings of education and school achievements in students' self-positioning, various forms of school absenteeism and compensation strategies for mitigating the effects of low school achievements. We gathered information in focus groups of secondary school students (72 students in 22 groups), and through in-depth interviews with the participants (44) in the programme 'Project-Based Learning for Young People (Early School-Leavers)'.

From discussions in two focus groups, conducted in one of the grammar schools in Ljubljana, it became clear that students would like to extend the conversation about their personal experience with school success or lack thereof, and (un)fulfilled expectations. We invited them to write (using pseudonyms) about their feelings about school, school achievement, reasons for under/achievement, experiences of parents' expectations and parents' reactions to their school achieve- 
ment. We received 22 personal records (the length of the material ranged between one and two pages) that provide insight into students' vulnerability, fears and anxieties, joy and pleasure, expectations and disappointments related to school achievement and (parental) expectations. These records also provide an insight into how students cope with the norms of a 'responsible, capable, good' student, and the stigma produced by these norms. These records form the empirical data used in this paper.

A relatively structured research technique (i.e. a set of open-ended research questions) and rather small amount of data facilitated the data analysis process. Records were analysed systematically with the following coding procedures. During the first pass through the written records, I defined the main themes in accordance with the initial questions mentioned above. Then I constructed categories (e.g. school achievement, criteria for its evaluation, responsibility, pressure, consequences, resistance, subjection/subjectification), and after defining each of them, I selected 'units of meaning' from students' written records and categorised them. At the end of the analysing process I examined substantive connections between categories (responsibility-pressure-motivation-achievement).

To explain the extension of pressure on school performance and fear of school failure among young people, I refer to previous surveys on the values and life orientations of young people in Slovenia $(1999,2000){ }^{1}$ To provide a wider contextual understanding of the subjective meaning of school success/failure, the pressure to perform and how students cope with failure and pressure (above all the prevailing attitudes towards education and the educational system), I offer some quantitative data from Slovenian public opinion surveys (from 1990s onwards). ${ }^{2}$

\section{Education as 'the best investment in oneself'}

Slovenia weathered the transition from socialism to capitalism without major political upheaval. Nevertheless, deregulation of the economy, growing unemployment (especially among young people), increasing income inequality and poverty, and impending reforms of the pension, health, and social security systems aroused feelings of unease and uncertainty. Governments from the early 1990s

\footnotetext{
1 These surveys were also conducted by the Centre for Social Psychology ISS FSS, University of Ljubljana. In 1999 the survey was based on a sample of 1687 14- to 15-year-old (final year) compulsory school students [Ule et al. 2000], and in 2000 the study was based on a sample of 1262 young people between the ages of 16 and 29 [Miheljak (ed.) 2002]. In the first one the questionnaire was administered in groups (at schools and faculties), while in the second face-to-face interviewing was used.

2 These surveys were conducted by the Public Opinion and Mass Communication Research Centre ISS FSS (CJM). Data is representative for the Slovenian adult population (the number of respondents varied from 1024 to 1050), and was collected through standardised face-to-face questionnaires.
} 
onwards have tried to legitimise the process of transferring responsibility for social and personal welfare from the state to individuals as a necessary condition for strengthening the competitiveness of the economy and the integration of Slovenia into the European Union. In conservative political discourse, social inequities were explained by individual merits and responsibility, and the principles of solidarity and social justice were often discredited as a remnant of a 'totalitarian regime' and as fear of freedom.

However, public opinion surveys at the time indicated (and still do) a high level of support for state responsibility for social welfare, and ensuring equal opportunities [Toš 2009]. The educational system and educational institutions are among the rare social subsystems that still enjoy a high level of public confidence in Slovenia. In studies of Slovenian public opinion from 1995 onwards, the viewpoint that predominates among the respondents (from all social classes) is that education is an important, even crucial factor for social success: respondents, for example, associate education with the possibility of a higher income; it is treated as a condition for 'achieving something in life', as a condition for social inclusion and employability [Toš 2004, 2009]. This can be explained in part by the objective features of educational policy. Namely, the reforms of the educational system (curriculum, financing, administration, etc.) were introduced gradually and were the subject of relatively widespread public debate. The state strived to preserve the accessibility of public education (tuition-free) at all levels of education, and the share of the younger generation (20-29 years) included in tertiary education has increased. However, the conclusion that this confidence is purely a consequence of an advantageous educational policy would be premature. Despite the relative openness and accessibility of the educational system, education is not equally accessible to all (the system is, for example, highly discriminatory towards the Roma), and the educational system must be selective to produce a diversified labour force needed by the market.

In conditions of increased unemployment among the young and a growing feeling of uncertainty, belief in education as a passport to a secure future, trust in the fairness of the educational system, and discourses on personal responsibility for academic achievement and 'employability' [cf. Edwards 2004] can reinforce the academic pressure on young people. Walkerdine, Lucey and Melody [2001], for example, have pointed out the contradictory effects of discourses on 'can do girls' and 'I can have everything' girls on the way of life and self-construction of young women of different classes.

Children experience performance pressure very early in their lives: this is indicated, for example, by data from a study on the social vulnerability of youth in Slovenia (see note 2): $96.5 \%$ of respondents (14- to 15-year-old compulsory school students) agree with the statement that for their parents 'a school certificate is very important'. Pressure for high academic achievement leads to 'open season on good marks' [Kvale 1981: 43] as early as at the compulsory school level. The share of A and B students in Slovenian compulsory school is quite high (in the last few years of compulsory school this proportion exceeds one-third) [Sta- 
tistical Office 2004, 2006, 2007, 2008], thus even small differences in school marks can decisively influence further educational opportunities. School marks are of great importance especially for those compulsory school pupils who intend to enrol in grammar school (gymnasium), which is the most desired form of secondary school in Slovenia, since it prepares students for study at the tertiary level of education and opens up the best opportunities for further study. Soon after the collapse of socialism, enrolment in grammar schools grew rapidly: the share of secondary students enrolled in grammar schools rose from 25\% in the 1996/1997 academic year to almost $40 \%$ in the $2006 / 2007$ academic year and even to $42.72 \%$ in 2010 [Krek and Metljak (eds.) 2011]. Owing to the growing interest in grammar schools and the larger population of compulsory school pupils in the 1990s and 2000s (the children of baby boomers), criteria for admission have been raised. Under such circumstances it is extremely difficult to be successful-every school mark which could hinder or even bar entry to the school desired is considered as failure.

For the children of parents with tertiary (and even secondary) education it is considered 'normal' that they will enrol in a grammar school after finishing the (nine-year) programme of compulsory schooling, while for others the grammar school is a sort of reward for being clever and hard-working. The following statement $^{3}$ (implicitly) draws attention to the symbolic meanings of educational choices:

After compulsory school I wanted to enrol in a secondary school for design, but my father insisted that I go to a grammar school. So I went. I didn't do well there, I didn't feel comfortable, and I didn't finish the school year. When I wanted to switch to design, my father yelled at me for being such a disgrace to him. (female, age 17, secondary technical school)

The same student related how some teachers at her former grammar school treated students there as more worthy than those from other secondary schools, and her peers (including grammar school students) in the focus group agreed with her. Their statements indicate the strong symbolic meaning of education and 'choices' in the field of education. Students in our research project were clearly aware that enrolment in a certain school gave them a certain social status. This does not mean that their educational desire is entirely determined by the dominant norm of the 'educated person' - 'our' female student is one of those who are not motivated by the symbolic status of grammar school. However, students' emotional reactions (feeling offended or even angry) in this instance indicate that the differences in the attributed symbolic statuses are not an insignificant factor in their self-understanding and social relations.

\footnotetext{
${ }^{3}$ This statement is from a focus group discussion conducted in a qualitative study 'The Genesis of School Success (Failure) and the Social Positioning of Less Successful Children' [Mencin Čeplak, Mrgole and Ilić Ratkai 2006].
} 


\section{School under/achievers and social inequalities}

The individualisation of responsibility in the field of education is also reflected in scientific and professional discourses on the factors of children's academic achievements. These discourses most frequently focus on the child's inherited factors and personal traits, his/her socio-economic background and parenting quality.

The 'quality of early child care' as an investment in the child's human capital is the subject of broad scientific investigation and professional concern and evaluation. Literature for 'young', 'caring', 'attentive' parents (above all aimed at mothers) emphasises the importance of intellectual stimulation, emotional support and care for the child's cognitive, emotional, social development and her/his future academic, professional, social success [e.g. Walkerdine 1984; Foucault 2008]. The infant has become a 'project', or, as Holmer Nadesan says [2002: 242-426], the potentiality realisable by attentive, responsible, and competent parents with the support of 'therapeutic interventions designed to engineer a perfect being ...' . The careful organisation of the child's daily life, choosing a good school and 'useful' extracurricular activities, urging her or him to work hard, encouraging her or him to be self-reliant are considered to be the qualities of the 'concerted cultivation' model of child-rearing, as Lareau [2003] calls it. But hegemonic discourses on 'good' parenting overlook the fact that these norms are by no means attainable for all parents; that differences in parenting styles are the result of social inequalities and at the same time have important implications for their reproduction; that parents from different social classes, ethnicities, 'races' are positioned differentially in relation to professionals and therefore react differently to their advice [Walkerdine 1984; Walkerdine, Lucy and Melody 2001; Holmer Nadesan 2002; Lareau 2003; Edwards and Gillies 2011].

Explicit or hidden pressure on parents increases further once the child starts attending school, when more or less intense involvement in the child's schoolwork and partnering with the school is expected of them. Just as with early child care, parental involvement in the child's schoolwork is shaped by social inequalities, which are reflected primarily in their own feelings of competence and experience of power in relationships with teachers and counsellors. As Crozier [1997, 2000] argues, middle-class parents' intervention in school 'could arguably be referred to as consumerist acts rather than examples of partnership' [ibid. 2000: 39]. Teachers are supervised, and they and the schools are expected to fulfil certain standards-in contrast with working-class parents, who leave school to teachers, the 'home-school partnership' is thus transformed into yet another of the praxes that differentiate, exclude, and reproduce marginal subject-positions and blame parents for their children's low school achievement. When educational policy and school practices overlook this and treat parental involvement regardless of context, they just deepen social inequalities.

A study of the parents of compulsory school children in Slovenia [Šteh 2008] also found that the degree of parental involvement in the child's school and school- 
work varied depending on how the parents evaluated their own competence. The author focused on the education of parents, and not social class in general, as a crucial factor in the differences. But research on school failure and achievement in Slovenia from the first major study in 1977 on emphasises the differential influence of the child's socio-economic background [e.g. Marjanovič Umek, Sočan and Bajc 2007]; however, only rarely is the concept of social class used. Namely, socioeconomic background is usually at least implicitly defined using Bourdieu's concept of social, cultural, and economic capital and their mutual interconnections. Thus the education of parents is emphasised as one of the crucial factors of school achievement, especially the education of the mother, since this is more strongly correlated with the child's school achievement than that of the father.

Researchers associate other crucial factors affecting school achievement with parents' education, such as the socio-economic status of the family, parents' expectations and aspirations, support, involvement in the child's school and schoolwork, intellectual stimulation, and also the child's curiosity, verbal skills, and 'general intelligence' [e.g. Marjanovič Umek, Sočan and Bajc 2007; Peček, Čuk and Lesar 2006; Lavrič (ed.) 2011]. However, the privileged position of children from such social environments has its price, as I will attempt to show below.

\section{‘Being the best' - and if not, what's wrong with me?}

Surveys on the values and life orientations of young people in Slovenia show that young people (from all social classes) regard academic achievement as very important in their lives, girls even more so than their male peers. For this reason, youth studies and studies on the factors and psychological consequences of low achievement and school failure draw attention to the pressure for school achievement and its negative psychological effects [Ule et al. 2000; Miheljak (ed.) 2002; Mencin Čeplak, Mrgole and Ilić Ratkai 2006; Tomori 2002]. Young people (and even children) are clearly aware of the expectations of their parents and the importance parents assign to their achievement in school. I consider it sufficient to mention only two of the widespread problems among children and teenagers associated with school: anxiety over school failure ${ }^{4}$ and a high level of discontent with school reports and school marks. ${ }^{5}$

However, there are some indicative differences among students according to their gender and the high school they attend. Academic success is even more important to girls than to their male peers (the differences are statistically

\footnotetext{
${ }^{4}$ In a survey of 14- to 15-year-old pupils (see note 2), 38.5\% of respondents found the fear of school failure as a 'very big personal problem', while another $45.7 \%$ considered it a 'problem' [Ule et al. 2000].

${ }_{5}$ The survey mentioned in the previous note found that not even A students are entirely satisfied with their achievement, while among B students only $36.6 \%$ are satisfied [Ule et al. 2000].
} 
significant). Like Skelton and Francis [2003], researchers in Slovenia have found that girls take responsibility for their underachievement upon themselves more than boys do, they are also on average noticeably more successful in school than boys, and the level of education attained by women is growing significantly more rapidly than that of men [e.g. Marjanovič Umek, Sočan and Bajc 2007; Mencin Čeplak 2002]. In a qualitative study on the genesis of school success/failure (focus groups), we found the lowest level of anxiety about school achievement among students at vocational secondary schools, and the highest among grammar school students-performance anxiety among grammar school students was almost the rule.

Grammar school students are a select population: they were the most successful students in compulsory school, i.e. the compulsory school 'winners', successfully interpellated as responsible, capable, 'promising' students, expected (and aspiring) to be winners. However, their privileged subject position upon entry to grammar school comes under threat, since competition due to the demands of the school and the greater number of ambitious students is intensified. If a student wishes to gain or retain a privileged position, she or he must expect heightened conditions of constant competition and the pressure of continuous examination. Examination is the most important instrument of school disciplinary power, because, according to Foucault [1984], it combines hierarchical surveillance and normalising judgement, and its documentary techniques make possible perpetual comparison of each and all: performances on a test, written reports, oral examinations, class behaviour, activities which present the school to the outside world. In Slovenia, the school report, based on school marks, is a decisive factor for secondary school enrolment and university admission criteria in Slovenia. ${ }^{6}$ School marks also have great symbolic significance since they are seen as an important indicator of students' abilities and parental competence.

The following statement expresses a student's anxiety caused by constant examination:

All the pressures of course, especially some of them, make us despair. I think we're all under too much pressure. Even when I get a good mark, of course I'm praised for it, but so what, the next day I'm under pressure again. (BeTheBest, male) ${ }^{7}$

All grammar school students in our research wrote that anxiety about low school marks is a great personal and emotional problem for them, and from their written

\footnotetext{
${ }^{6}$ In the case of a limited number of places for students, the key university admission criteria in Slovenia are achievement on the secondary national school-leaving exam (60\%) and achievement in the last two years of schooling (40\%).

7 This and the following statements are from written reports gathered in a qualitative study 'The Genesis of School Success (Failure) and Social Positioning of Less Successful Children (17- to 18-Year-Old Grammar School Students)'. The names of all the students are pseudonyms (e.g. 'BeTheBest'), created by the students themselves.
} 
notes it is clear beyond a doubt that school powerfully impacts all areas of their life. If they 'neglect' their schoolwork, at best it seems to them 'not good', and at worst they end up in a vicious circle of failure and blame:

... right now my social life is more important to me than my education. I know this isn't good, since education is very important for later life. Good marks are a bright spot for me at school, as well as the fact that this makes my parents happy and they will then allow me more free time to have fun. (Sanja, female)

If I get a failing mark, I feel horrible, I have a bad feeling, I'm angry with myself and with my teacher. Sometimes as a result of this anger I do something stupid. (JPS, male)

My personal problem is that I've lost all motivation for studying because of all these failures. (Tim, male)

One of the key factors of anxiety is the fact that students are clearly aware that school marks are a crucial determining factor in their transition along the educational path. Tim, who had many failing marks in the current school year, assessed his chances of being accepted for the course of his choice as follows:

My goal was to enrol at the Faculty of Arts, where I would like to study English, but this faculty is physically and mentally becoming unattainable as a result of this year, not to mention the criteria I need to meet to be accepted.

Sanja's statement, cited above, indicates the importance of parental support, understanding, and confidence in dealing with anxiety about school failure/success. Nana, for example, wrote: 'It means a lot to me that my parents support me even if I fail.' The flipside of the importance that students ascribe to parental support are the negative effects of parents' excessive expectations for their children's academic achievement. These can exacerbate children's anxiety, or even become the main source of it. The next statement indicates the burden of parental (and teachers') pressure and its counter effect:

... I think that parents and teachers emphasise too much that if you get a failing mark, you'll have to re-take the exam, if you fail, there will be problems ... and as a result I'm personally under unnecessary pressure which only does harm. (Alfa 2, male)

One of our respondents (Tina, female) wrote about her experiences with extremely critical parents, their deep mistrust and even underestimation of her. When she got the highest mark she expected a positive response but instead most of the time she heard: 'Yes, but when will you improve that failing grade in math?' 
The burden of parental pressure is much heavier when parents interpret bad school marks as a sign of the child's moral and/or intellectual inferiority:

... for my parents only school is important. If I'm not successful in school, I'm a bad person, irresponsible, 'incapable', and so on. (Mitja, male)

... What bothers me most is that when I get a failing grade, Mum gets all worried and then thinks that everything I do wrong, I do to make her worry. Which is simply not true. (Josip Broz, ${ }^{8}$ male)

It appears that students are most affected by the criticisms from their parents, who accuse them of not caring about their marks, whereas in fact all the students who have even occasional difficulties due to low school marks stress how emotionally upsetting it is for them to receive low marks-and all the more so, if parents react with accusations, threats, and punishment. These students at least implicitly express disappointment in their parents-disappointment that parents focus their parental role too much on controlling their schoolwork while neglecting the affective dimensions of the parent-child relationship [see Montandon 2002]. Sanja expressed this disappointment most radically:

... my friends show a greater understanding for one of my problems than my parents do for 10000 of my problems, and that makes me angry. And I wonder why the hell they bothered to have me, if they have no understanding for my problems.

The moral judgment of those who 'don't work hard enough' is a significant source of pressure, blame, and fear-the punishment for not working hard enough is not only a poor mark, but also (or even primarily) moral condemnation. School failure is interpreted as a symptom of a moral fault ('a bad person', 'irresponsible'), and we can agree with Fine [1994] who has drawn attention to the construction of 'moral boundaries of deservedness'. The grammar school students in our study appear to internalise the norm of the 'good', 'moral', 'grateful' child, which presumably also includes working diligently in school, and this norm operates as the criterion on whose basis they judge themselves and their 'value'. Statements about how strongly they are affected by failing marks attest to these feelings of guilt, since they have failed to meet their own expectations as well as those of their parents.

Mitja also drew attention to one of the most widespread yet fatal psychological 'truths', which has a strong influence on the subject position and identity of less successful students: to be unsuccessful means to be 'incapable', i.e. the assumption of the causal relationship between 'intelligence' (cleverness) and school

8 This name has a special meaning in Slovenia: it is the name of the first president of the former (socialist) Yugoslavia, Josip Broz Tito (1892-1980). 
achievement. Notwithstanding the long history of criticisms of the concept and technologies of measuring intelligence [e.g. Gould 1981; Tort 1984], the conviction that there exists a general intellectual capability which can be accurately and reliably measured, on the basis of which academic success may be predicted, remains rife not only in common sense but even in scientific analyses of school achievement [e.g. Laidra, Pullmann and Allik 2007]. The assumption of the correlation between 'intelligence' (cleverness) and school achievement creates, in advance, categories of incapable or even 'stupid' students, and legitimates (implicitly or explicitly) the devaluation and underestimation of children with low school achievement.

School achievement can become a central issue in parent-child relationships, which structures the relationships in the family. There are at least two reasons for this: parents' fear that their child's failure at school will result in his or her future being 'squandered', insecurity about their own performance in the role of parents. As noted earlier, a child's underachievement is often considered a reflection of parental incompetence, neglect, indifference, and immaturity. School achievement sends a message about how well parents have performed their parenting role-especially mothers. As noted by Griffith and Smith [2005], the shift in responsibility for education from the state and schools onto the family means above all an increase in hidden gendered labour and in the culpability of women and especially single mothers.

The sharing of responsibility among students and their parents thus does not alleviate the burden of eventual school failure - on the contrary, it even increases it. Children's (school) success becomes the measure of parents' (and teachers') competence, care and love, and at the same time the proof of the child's love for her/his parents (as is evident in Mitja's and Josip Broz's statements). This means that parents (and teachers) themselves are exposed to the constant pressure to 'be the best'. In this vicious circle the feelings of responsibility and blame deepen. Attempts to transfer responsibility from parents to children-and vice versa-even in the best of cases only relax the tension for one party (for a short period) at the expense of another (and over the long term this, too, becomes a source of blame). Relationships between children and parents are further complicated by a fundamental contradiction in these relationships: the contradiction 'between connectedness and discipline, or regulation', between the young person's need for autonomy and the necessity of parental control, where it is difficult to 'find a suitable middle ground' [Backe-Hansen 2002: 179; see also Ericsson and Larsen 2002].

The feelings of blame and shame which burden less successful children (and their parents) are considered as punishment for lack of effort and merit-just like poverty, disease, victimisation, and physical unattractiveness. Mitja's experience with parental response to his 'failure' ('If I'm not successful in school, I'm a bad person, irresponsible, "incapable", and so on') implicitly draws attention to the normative function of 'psy'- sciences and scientific categorisations, one that in- 
dividualises and pathologises school failure. The individualisation and pathologisation of school failure, which is otherwise the result of the complex mutual interaction of social practices, ideologies, and specific strategies of tackling obstacles along the educational path, is an important factor in the process of stigmatisation and discrediting - it places the individual in a 'negatively valued social category' [Goffman 1976: 11-12]. According to Foucault [1984], classification in human sciences creates a special map of categories, which direct the focus of attention to potentially problematic individuals, and 'offers a deceptive image of an isolatable and identifiable group of students who, by virtue of some personal characteristics, are not likely to graduate' [Fine 1990: 64]. The social meanings of these categories guide expectations and co-construct identities and their values.

\section{Coping with performance pressure: submission and resistance}

The subject-position in the field of education is strongly dependent on the deviations from the norm of the 'good student', which refers, first of all, to a student's school marks, motivation, school work, doing homework, abilities, and also to her/his behaviour, speech, respect for authority, and integration in school life [e.g. Coronel Llamas 2006].

The ultimate fulfilment of the norm of the 'good' student is to become 'the best'. 'BeTheBest', the name one of our young interviewees took for himself, summarises this principle of late capitalist societies. This principle demands endless work-at school and at the workplace, to improve oneself, to improve one's image, to improve one's personal relationships. 'Be the best' could be a hidden parental desire, which children understand as a demand, one which can never be met [e.g. Lasch 1991]. The child is subjected to the imperative of getting ahead of others, which implies a deep fear of being labelled a 'loser' or even a fear of being just 'average'.

To become responsible, rational adults, good citizens, and good students, young people not only have to attend school, learn, do their homework, get good school marks, and behave properly - they are also expected to desire to be good, responsible students and citizens, and they are expected to actively govern themselves according to these norms. Such voluntary submission of individual subjects to the norms is, according to Foucault [2000], a consequence of the successful deployment of power-discourses on good students are successful when they arouse in individuals a desire to be a good student.

Taking responsibility for failure, including 'moral fault', is one of the results of 'successful' subordination to this norm. In our study on the genesis of school success/failure, students do question the unfairness of the school system and school praxes, they do question the methods of teaching; they do perceive that teachers are clearly more favourably disposed towards successful pupils; they criticise parental pressure-but all of them first of all assign responsibility for 
their achievement to themselves [Mencin Čeplak, Mrgole and Ilić Ratkai 2006]. The statements of the grammar school students indicate that they try to cope with the burden of the imperative of school achievement by investing more effort in school, but this achievement is not guaranteed.

Performance pressure itself can have just the opposite effect of what those who exert the pressure expect. Students (nine of them) in our study also explicitly stressed the negative effect of constant school pressure and accumulation of bad school marks (despite their hard work):

... I experience stronger feelings when I get a bad mark than when I get a good one, since if I get a $5 \mathrm{I}$ ' $m$ happy and satisfied for a bit, but if I get a 1, I'm overwhelmed by negative emotions and I worry about the mark a lot longer. And personally I think that someone who isn't influenced much by which mark they get can complete the year a lot more easily, since they're not too depressed when they get a poor mark and when they need to fix it they don't fall into paranoia about failing again. (Alfa 2, male)

... when parents give me a hard time because of my poor marks, it doesn't motivate me at all to study harder, it just makes me resist them and the teachers at school even more. (Sanja, female)

If, for example, you study in order to bring up a failing mark and you're not successful, then you acquire a sort of resistance or just put off working, since you think you'll take care of it later. Soon you realise that you can't fix it and then you give up. The pressure is really heavy, from teachers, too, since eventually so many things pile up that you lose all interest and enjoyment in going to school and start to wonder whether it's worth going at all. (BeTheBest, male)

Sanja and BeTheBest explicitly wrote about resistance. Resistance is, according to Foucault, an inevitable and essential element within power relations-if there is no possibility of resistance, then we are dealing with domination and not with power, which is, according to Foucault, relational [2000]. Resistance takes many forms, from passive to active, from delaying or avoiding schoolwork or even giving up, when no effort pays off, and pressure becomes unbearable; from more or less conscious opposition to school norms to conscious resistance to inequalities and injustice [see Aronowitz and Giroux 1993]. In each case the imperative of success produces numerous side effects that even subvert its declared aims, since it can, according to Althusser [1980], also be interpreted as a consequence of contradictions in the normative order. We can interpret just the choice of the name 'BeTheBest' as an indicator of unique resistance or at least imperfect submission to the norm of success: on the one hand the student who chose it implicitly expressed the desire in his statements to fulfil expectations and become at least 'good', if not already 'the best'. At the same time, he is more or less clearly aware that that ideal is not achievable, and thus he expresses a certain degree of 
irony with the name. The greater the disappointment because the goal is receding, the greater the resistance to school — even so great that the student starts 'to wonder whether it's worth going at all'. So low school marks could be considered not only as a kind of punishment for 'laziness', irresponsibility, inability or lack of motivation, but also as a failure of the disciplining technique of hierarchical observation, normalisation, and examination.

However, low school achievement is expected, even inevitable, since school must produce differences in order to regulate access to education and ensure a diversified labour force. Even radical resistance to education (the radical rejection of school), which does indeed have unintentional consequences, is expected-it is calculated in the educational system and social order that underachievers are punished through marginalisation. Fear of marginalisation, especially for children from privileged social classes, operates more or less as a form of soft coercion. Similar to what Foucault claims about prison [1975], we could say that school underachievement is also in fact a success of the system, since it must produce success and failure.

Nevertheless, oppositional behaviour and resistance demonstrates that submission to the imperative of school success is not perfect or uniform. The contradictory nature of the norm itself of the 'good student' ensures that this be so. Namely, to be a good student also implies submission, which is counter to the norm of nonconformist, rebellious youth. Jackson [2010: 47-48], for example, writes about the 'uneasy relationship' between fears of social failure (i.e. being unpopular) and fears of academic failure. She treats these two sets of fears 'as competing fears and fears about competition in that they are incompatible' [italics Jackson's]. Lower marks in many school environments signify one who is a nonconformist, rebellious, 'cool', i.e. exactly the image which fits the norm of rebellious youth, or more precisely: the norm of a 'real boy'. Analysis of the genesis of school success/failure in Slovenia indicates that negative peer pressure is more common in vocational than in grammar schools [Mencin Čeplak, Mrgole and Ilić Ratkai 2006], but in written reports grammar school students did not even mention this kind of pressure, and this can be at least partially explained by the same factors which influence the 'choice' of secondary school described in an earlier section of this article.

The division into achievers and underachievers is of course problematic due to the numerous criteria of (under)achievement; the boundaries between achievement and underachievement are not clear and unambiguous; evaluations of achievement are contradictory. Despite the unclear boundaries it seems reasonable to draw attention to at least one difference between underachievers implicating their reputation and power. In the first category we could place students who consciously reject the school order and the imperative of school success, etc. In the second are categorised all those for whom it is assumed that they cannot fulfil the norm of success. To school underachievers, for whom, presumably, bad school marks are their more or less conscious resistance to school disciplinary 
strategies and norms of success, the label 'bad student' is often applied. It implies disobedience, defiance, resistance; the 'bad student' is one who is believed to be indifferent to success or even does not want to achieve it, i.e. one who flouts school norms (or even social norms in general). In contrast, to be 'unsuccessful' means to be incompetent, incapable, to have low potential (or 'human capital'). It is a label for someone who cannot achieve success, who does not have a choice.

For this reason the label 'unsuccessful student' is a considerably more fateful stigma than the label 'bad student'. In education, students who are labelled as 'incapable' are from the standpoint of identity among the most tragic victims of social inequalities and the imperative of success.

Schools perform disciplinary and normalising functions not only through the norm of the good student, but also at least partially through the norm of schooling youth. Namely, in contemporary societies 'to be young' means 'to be in school'. Students stay young, since in public discourse youth is generally treated as the generation in school. This belief could make the burden of responsibility for school achievement even heavier. But on the other hand, those who stay in the system despite their difficulties maintain a peer network, which can be an important source of self-esteem. As the analysis of the genesis of school success/failure in Slovenia indicates, even with all the discomfort it causes, school life is nevertheless a source of pleasure for most (in their written reports only one student expressed negative feelings about school):

I have a good time at school because of my classmates, socialising, friendships ... I really like going to school, even though I get poor marks. (Josip Broz, male)

However, different modes of coping with the norm of the 'good' student and success do not mean that everything is possible. Subject positions are not absolutely freely chosen, it is not the child or student who determines the criteria and meanings of being successful or unsuccessful, smart or not smart, worthy or not worthy - the 'truths' about the child are constructed by psychological theories, pedagogy, parents, teachers, prejudices, the norms of efficiency and economic profit.

\section{Conclusion}

This article contributes to governmentality studies in the field of education. By applying Foucault's concept of governmentality, I attempted to analyse the disciplining and normalising effects of awareness (or even fear) of school failure in the context of transferring responsibility for social and personal welfare from the state to individuals in Slovenia, where education is considered as a good 'personal' investment in the future. Qualitative analysis of grammar school students' written reports shows how the illusion that hard work ensures success and pro- 
vides security, acceptance, even love, leads to the exacerbation of conditions of competition. It creates a vicious circle of great expectations, hard work and competition, that instead of improving in fact limits young people's options. I tried to point out the complex and ambiguous operation of normative power: on the one hand, students in their written reports express their willingness to fulfil the norm of the good student and the educated person, for the sake of their own well-being and good life prospects, or just for the sake of a good relationship with their parents (and teachers), but on the other hand, they also express a certain degree of discontent and resistance to this norm and (parental) expectations. Thus this study shifts from Foucauldian-inspired educational research that 'overlooks' the (potentially) emancipatory role of education and resistance to the 'ruling norms' in the field of education.

This analysis implicitly draws attention to the consequences of more stringent conditions for accessing education. In Slovenia we could already see strong pressure on school performance even during a period of relative prosperity; in the current economic crisis we can only expect this to intensify. The government which took office in January 2012 is making cuts primarily to the public sector as a means of dealing with the crisis. Proposed measures such as increasing the number of students per class and the elimination of smaller schools will affect everyone, and cutting wages in the public sector and reducing grammar school places will impact primarily (at least initially) families and children of educated parents who are employed in the public sector, who up until now have been regarded as a privileged social class and who have had on average higher educational aspirations. Rationing education can lead to a form of 'rationalising of human resources', which would legitimate early differentiation of children based on expected academic achievements, related to pre-established categorisation; it might reinforce the negative evaluation of children from deprivileged social classes, cultures, social groups, and impose negative norms of identification on them [e.g. McLaren 1993].

In this context, it is also worth emphasising the role of theory in educational policies. As Henriques et al. [1984: 12] write, theory is not innocent: 'All theory is conditioned by historically specific circumstances and has definite effects on social existence'. If the (theoretical) conceptualisation of individual/social relations and the studies and research on school failure or achievement ignore power relations, social inequities, the (un)fairness of the educational system and policies, then in the final instance they attribute the causes of social differentiation and inequalities to individuals (to their nature or to their (free) choice) - and thereby increase the burden of individual responsibility.

MetKa Mencin ČeplaK lectures on social and political psychology and identities at the Faculty of Social Sciences of the University of Ljubljana (Slovenia). Her main research interests are the construction of stigmatised identities and the (re)production of power 
relations. Recently published articles include: 'Stigmatization, Identity Politics, and Power Relations' (Dialogi, 2008); 'Gender/Sexual Norms, Legitimation of Exclusion and School' (Sodobna pedagogika, 2009); 'Gender Inequalities in Education' (with Veronika Tašner, Brez spopada, 2009); 'Fights for Equality_From Discrimination of Homosexuality to Redefinition of Family' (with Roman Kuhar, Socialno delo, 2010).

\section{References}

Althusser, Louis. 1980. 'Ideologija in ideološki aparati države.' (Ideology and Ideological State Apparatus) Pp. 39-99 in Ideologija in estetski užitek, edited by Zoja Skušek Močnik. Ljubljana: Cankarjeva založba.

Apple, Michael W. 1996. Cultural Politics and Education. New York: Teachers College Press. Apple, Michael W. 2001. Educating the 'Right' Way: Markets, Standards, God, and Inequality. New York: Routledge.

Apple, Michael W. 2004. 'Creating Difference: Neo-Liberalism, Neo-Conservatism and the Politics of Educational Reform.' Educational Policy 18 (1): 12-44.

Aronowitz, Stanley and Henry A. Giroux. 1993. Education Still under Siege. Westport, CT: Bergin \& Garvey.

Backe-Hansen, Elisabeth. 2002. 'Young People between Home and School.' Pp. 172-187 in Children, Home, and School: Autonomy, Connection, or Regulation?, edited by Rosalind Edwards. London: Routledge.

Ball, Stephen J., Richard Bowe and Sharon Gewirtz. 1994. 'Market Forces and Parental Choice.' Pp. 13-25 in Educational Reform and Its Consequences, edited by Sally Tomlinson. London: Rivers Oram Press.

Coronel Llamas, José Manuel. 2006. 'Technologies of Disciplinary Power in Action: The Norm of the "Good Student".' Higher Education 52 (4): 665-686.

Crozier, Gill. 1997. 'Empowering the Powerful: A Discussion of the Interrelation of Government Policies and Consumerism with Social Class Factors and the Impact of This upon Parent Interventions in Their Children's Schooling.' British Journal of Sociology 18: 187-201.

Crozier, Gill. 2000. Parents and Schools: Partners or Protagonists? Stoke-on-Trent: Trentham Books.

Dale, Roger. 1997. 'The State and the Governance of Education: An Analysis of the Restructuring of the State-Education Relationship.' Pp. 273-282 in Education: Culture, Economy, Society, edited by A. H. Halsey, Hugh Lauder, Phil Brown and Amy Stuart Wells. Oxford: Oxford University Press.

Edwards, Rosalind. 2004. 'Intellectual Technologies in Fashioning the Learning Society.' Educational Philosophy and Theory 36 (1): 69-78.

Edwards, Rosalind and Pam Alldred. 2000. 'A Typology of Parental Involvement in Education Centering on Children and Young People: Negotiating Familialisation, Institutionalisation and Individualisation.' British Journal of Sociology of Education 21 (3): 435-455.

Edwards, Rosalind and Val Gillies. 2011. 'Clients or Consumers, Commonplace or Pioneers? Navigating the Contemporary Class Politics of Family, Parenting Skills and Education.' Ethics and Education (Special Issue) 6 (2): 141-154.

Ericsson, Kjersti and Guri Larsen. 2002. 'Adults as Resources and Adults as Burdens. The Strategies of Children in the Age of School-Home Collaboration.' Pp. 92-105 in 
Children, Home, and School: Autonomy, Connection, or Regulation?, edited by Rosalind Edwards. London: Routledge.

Fine, Michelle. 1990. 'Making Controversy: Who's at Risk?' Journal of Urban and Cultural Studies 1 (1): 55-68.

Fine, Michelle. 1994. 'Working the Hyphens: Reinventing Self and Other in Qualitative Research.' Pp. 70-82 in Handbook of Qualitative Research, edited by Norman K. Denzinand and Yvonna S. Lincoln. London: Sage.

Foucault, Michel. 1984. Nadzorovanje in kaznovanje: Rojstvo zapora. (Discipline and Punish: The Birth of the Prison) Ljubljana: DZS.

Foucault, Michel. 2000. Volja do znanja: Zgodovina sesksualnosti, Vol.1. (The Will to Knowledge: The History of Sexuality, Vol. 1) Ljubljana: Založba ŠKUC.

Foucault, Michel. 2008. The Birth of Biopolitics: Lectures at the College de France 1978-1979. New York: Palgrave.

Gillborn, David and Deborah Youdell. 2000. Rationing Education: Policy, Practice, Reform and Equity. Buckingham: Open University Press.

Goffman, Erving. 1976. Stigma. Notes on the Management of Spoiled Identity. London: Pelican/Penguin Books.

Gould, Stephen J. 1981. The Mismeasure of Man. New York and London: W. W. Norton $\&$ Co.

Graham, Cameron and Dean Neu. 2004. 'Standardized Testing and the Construction of Governable Persons.' Journal of Curriculum Studies 36 (3): 295-319.

Griffith, Alison and Dorothy Smith. 2005. Mothering for Schooling. New York: Routledge.

Henriques, Julian, Wendy Hollway, Cathy Urwin, Couze Venn and Valerie Walkerdine. 1984. Changing the Subject: Psychology, Social Regulation and Subjectivity. London and New York: Methuen \& Co. Ltd.

Hill, Dave. 2003. 'Global Neo-Liberalism, the Deformation of Education and Resistance.' Journal for Critical Education Policy Studies 1 (1). Retrieved 13 February 2012 (http://www.jceps.com/?pageID=article\&articleID=7).

Hirtt, Nico. 2008. 'Marketisation of Education in the Globalised Economy.' Retrieved 14 March 2012 (http://www.skolo.org/spip.php?article940\&lang=fr).

Holmer Nadesan, Majia. 2002. 'Engineering the Entrepreneurial Infant: Brain Science, Infant Development Toys, and Governmentality.' Cultural Studies 16 (3): 401-432.

Jackson, Carolyn. 2010. 'Fear in Education.' Educational Revieww 62 (1): 39-52.

James, David, Diane Reay, Gill Crozier, Phoebe Beedell, Sumi Hollingworth, Fiona Jamieson and Katya Williams. 2010. 'Neoliberal Policy and the Meaning of Counterintuitive Middle-Class School Choices.' Current Sociology Special Issue on Education in a Globalizing World 58 (4): 623-641.

Kaščák, Ondrej and Branislav Pupala. 2010. ‘Neoliberalna guvernmentalita v socialnom projektovani vzdelavania.' (Neoliberal Governmentality in the Social Designing of Education) Sociologicky časopis/Czech Sociological Review 46 (5): 771-799.

Kaščák, Ondrej and Branislav Pupala. 2011. 'Governmentality-NeoliberalismEducation: The Risk Perspective.' Pedagogicky časopis 20 (2): 145-158.

Krek, Janez and Mira Metljak (eds.). 2011. Bela knjiga. (White Book) Ljubljana: Zavod RS za šolstvo.

Kvale, Steiner. 1981. Izpiti in gospostvo. (Exams and Domination) Ljubljana: Krt.

Laidra, Kaia, Jüri Pullmann and Helle Allik. 2007. 'Personality and Intelligence as Predictors of Academic Achievement: A Cross-Sectional Study from Elementary to Secondary School.' Personality and Individual Differences 42: 441-451.

Lareau, Annette. 2003. Unequal Childhoods: Class, Race, and Family Life. Berkeley, CA: University of California Press. 
Lasch, Christopher. (1979) 1991. The Culture of Narcissism: American Life in an Age of Diminishing Expectation. New York: W. W. Norton.

Laval, Christian. 2005. School Is Not a Company: Neoliberal Attack on Public Education. Ljubljana: Krtina.

Lavrič, Miran (ed.). 2011. Mladina 2010. (Youth 2010) Ljubljana: Ministrstvo za šolstvo in šport, Urad RS za mladino; Maribor: Aristej.

Marjanovič Umek, Ljubica, Gregor Sočan and Katja Bajc. 2007. 'Vpliv psiholoških dejavnikov in izobrazbe staršev na učno uspešnost mladostnikov.' (The Effect of Psychological Factors and Parental Education on Adolescents' Academic Achievement) Psihološka obzorja 16 (3): 27-48.

McLaren, Peter. 1993. Schooling as a Ritual Performance. London and New York: Routledge.

Mencin Čeplak, Metka. 2002. 'Šola, služba in tiha nezadovoljstva.' (School, Job and Silent Dissatisfaction) Pp. 165-183 in Mladina 2000, edited by Vlado Miheljak. Ljubljana: Ministrstvo za šolstvo, znanost in šport, Urad republike Slovenije za mladino; Maribor: Aristej.

Mencin Čeplak, Metka, Albert Mrgole and Jana Ilić Ratkai. 2006. ‘Geneza šolske (ne)uspešnosti. Neobjavljeno raziskovalno poročilo.' (The Genesis of School Success (Failure)) Unpublished research report. Ljubljana: Fakulteta za družbene vede, Inštitut za družbene vede, Center za socialno psihologijo; Ljubljana: Ministrstvo za šolstvo in šport.

Miheljak, Vlado (ed.). 2002. Mladina 2000. (Youth 2000) Ljubljana: Ministrstvo za šolstvo, znanost in šport, Urad republike Slovenije za mladino; Maribor: Aristej.

Montandon, Cleopatra. 2002. 'Home and School Constraints in Children's Experience of Socialisation in Geneva.' Pp. 106-120 in Children, Home, and School: Autonomy, Connection, or Regulation?, edited by Rosalind Edwards. London: Routledge.

Muršak, Janko. 2010. 'General Education in the Function of Labour Market Needs and/or Personal Development and the Notion of Literacy.' Odgojne znanosti 12 (1): 185-196.

Peček Čuk, Mojca and Irena Lesar. 2006. Pravičnost slovenske šole: mit ali realnost? (Fairness of Slovenian School: Myth or Reality?) Ljubljana: Sophia.

Pongratz, Ludwig A. 2011. 'Controlled Freedom-The Formation of the Control Society.' Pedagogicky časopis 20 (2): 161-172.

Popkewitz, Thomas S. and Marie Brennan. 1998. 'Reconstructing of Social and Political Theory in Education: Foucault and a Social Epistemology of School Practices.' Pp. 3-35 in Foucault's Challenge: Discourse, Knowledge, and Power in Education, edited by Thomas S. Popkewitz and Marie Brennan. New York and London: Teachers College Press.

Robertson, Susan and Roger Dale. 2002. 'Local States of Emergency: The Contradictions of Neo-liberal Governance in Education in New Zealand.' British Journal of Sociology of Education 23 (3): 463-482.

Rose, Nikolas. 1990. Governing the Soul. London and New York: Routledge.

Rose, Nikolas. 1999. Powers of Freedom: Reframing Political Thought. Cambridge: Cambridge University Press.

Skelton, Christine and Becky Francis. 2003. 'Introduction. Boys and Girls in the Compulsory Classroom.' Pp. 3-25 in Boys and Girls in the Compulsory Classroom, edited by Christine Skelton and Becky Francis. Maidenhead: Open University Press / McGraw Hill.

Statistical Office of the Republic of Slovenia. 2004. Statistical Information 9. Ljubljana: Statistical Office of the Republic of Slovenia.

Statistical Office of the Republic of Slovenia. 2006. Statistical Information 19. Ljubljana: Statistical Office of the Republic of Slovenia. 
Statistical Office of the Republic of Slovenia. 2007. Statistical Yearbook. Ljubljana: Statistical Office of the Republic of Slovenia.

Statistical Office of the Republic of Slovenia. 2008. Statistical Information 28. Ljubljana: Statistical Office of the Republic of Slovenia.

Šteh, Barbara. 2008. ‘Učitelji in starši v očeh drug drugega pri "medsebojnem sodelovanju".' (Teachers and Parents and Their Cooperation in Each Other's Eyes) Sodobna pedagogika 59 (5): 30-50.

Tomori, Martina. 2002. ‘Šolska neuspešnost kot dejavnik tveganja za celostni osebnostni razvoj.' (School Failure as a Risk Factor on Holistic Personality Development) Pp. 16-18 in Šolska neuspešnost med otroki in mladostniki: vzroki, posledice, preprečevanje, edited by Katra Bergant and Kristijan Musek Lešnik. Ljubljana: Inštitut za psihologijo osebnosti.

Tort, Michel. 1984. Inteligenčni kvocient. (Intelligence Quotient) Ljubljana: Delavska enotnost.

Toš, Niko (ed.). 2004. Vrednote v prehodu III. Slovensko javno mnenje 1999/2004. (Values in Transition III. Slovene Public Opinion 1999/2004) Ljubljana: Fakulteta za družbene vede, IDV-CJMMK.

Toš, Niko (ed.). 2009. Vrednote v prehodu IV. Slovensko javno mnenje 2004/2009. (Values in Transition IV. Slovene Public Opinion 2004/2009) Ljubljana: Fakulteta za družbene vede, IDV-CJMMK.

Ule, Mirjana, Tanja Rener, Metka Mencin Čeplak and Blanka Tivadar. 2000. Socialna ranljivost mladih. (Social Vulnerability of Young People) Ljubljana: Ministrstvo za šolstvo in šport, Urad RS za mladino; Šentilj: Aristej.

Vincent, Carol and Sally Tomlinson. 1997. 'Home-School Relationships: “The Swarming of Disciplinary Mechanisms"?' British Educational Research Journal 23 (3): 361-379.

Walkeridne, Valerie. 1984. 'Developmental Psychology and the Child-Centred Pedagogy: The Insertion of Piaget into Early Education.' Pp. 153-202 in Changing the Subject: Psychology, Social Regulation and Subjectivity, edited by Julian Henriques, Wendy Hollway, Cathy Urwin, Couze Venn and Valerie Walkerdine. London and New York: Methuen \& Co. Ltd.

Walkerdine, Valerie, Helen Lucey and June Melody. 2001. Growing Up Girls. Psychosocial Exploration of Gender and Class. Hound mills, Basingstoke and Hampshire: Palgrave.

Webb, Taylor P. 2007. 'Accounting for Teacher Knowledge: Reterritorializations as Epistemic Suicide.' Discourse: Studies in the Cultural Politics of Education 29 (3): 279-295.

Webb, Taylor P., Felecia M. Briscoe and Mark P. Mussman. 2009. 'Preparing Teachers for the Neoliberal Panopticon.' Educational Foundations 23 (3-4): 3-18.

Whitty, Geoff, Edwards Tony and Sharon Gewirtz. 1993. Specialization and Choice in Urban Education. London: Routledge. 